\title{
Tedesko's Philadelphia Skating Club: Refinement of an Idea
}

\author{
Edmond P. Saliklis, M.ASCE${ }^{1}$; David P. Billington, Hon.M.ASCE${ }^{2}$; and Anneliza W. Carmalt, M.ASCE ${ }^{3}$
}

\begin{abstract}
This paper presents new aspects of Anton Tedesko's design for an important thin shell concrete roof. The study of this roof results from the examination of original engineering drawings and calculations which we present with the goal of promoting a greater understanding of the structural design of a major figure in the tradition of 20th century building.
\end{abstract}

CE Database subject headings: Thin shell structures; Conceptual design; Historic sites; Roofs; Structural engineering; Technology transfer.

\section{Introduction}

The purpose of this study is to document design ideas that Anton Tedesko realized in his Philadelphia Skating Club in late 1937. This documentation traces the development of an important work by a major designer. Tedesko was not the builder, but his building experience at the precedent setting, Hershey Ice Arena (Saliklis and Billington 2003), shaped his design ideas. Documenting such design ideas is important as structural concrete has now been in use for over a century and has completely embedded itself in our industry. Over this period of the last 100 years, we have gained substantial experience with this material. Some of the best examples of well-designed concrete structures are still in service 50-75 years after construction and therefore merit close study for developing a firmer basis for sustainable structures in the future.

Now at the dawn of the 21 st century two new opportunities arise for finding a new creativity in design of concrete structures. First is the issue of sustainability which for structural design means forms and materials that will show superior endurance over time, and second is the rediscovery of thin shell concrete structures. Both of these require a study of the best works of the 20th Century, through present day analysis, field observation, and the documentation of their designers' ideas and activities.

Unfortunately, the risk of losing creativity in design is quite real today and it begins by restricting engineering education solely to standard design courses at the undergraduate level. This approach to design, encouraged by emphasizing textbook problems that have little or no reference to actual built structures, is

\footnotetext{
${ }^{1}$ Assistant Professor, Dept. of Architectural Engineering, California Polytechnic State Univ., San Luis Obispo, CA 93407. E-mail: esalikli@ calpoly.edu

${ }^{2}$ Gordon Y.S. Wu Professor of Engineering, Dept. of Civil and Environmental Engineering, Princeton Univ., Princeton, NJ 08544.

${ }^{3}$ EIT Civil Engineer, KlingStubbins, Philadelphia, PA 19103.
}

essential but incomplete. Students also need to be exposed to the many modern designs that are efficient, economical and elegant and whose forms come from the imagination of structural engineers. It is important that students be taught to analyze structural elements to see whether or not they meet prescribed code provisions, but it is equally important that they have one course that introduces them to the finest engineering designs already built and performing well.

The second issue is more subtle, but no less significant. In recent years, popular media and our own professional journals have exalted the newest eye-catching forms that have arisen from a sculptor's perspective and can only be realized by high cost and overly complex structure. The physical understanding of the mechanics of these forms is delegated to an unwavering trust in the validity of the computer models. Thus, this second danger is really a product of the first danger, namely that structural engineers have come to believe that if clients want beauty, they must hire a sculpturally minded designer. If students are not educated in the grand tradition of engineering which demonstrates visually appealing and structurally efficient forms, then it is no wonder that the task of creating such forms in industry has often been left to other professions.

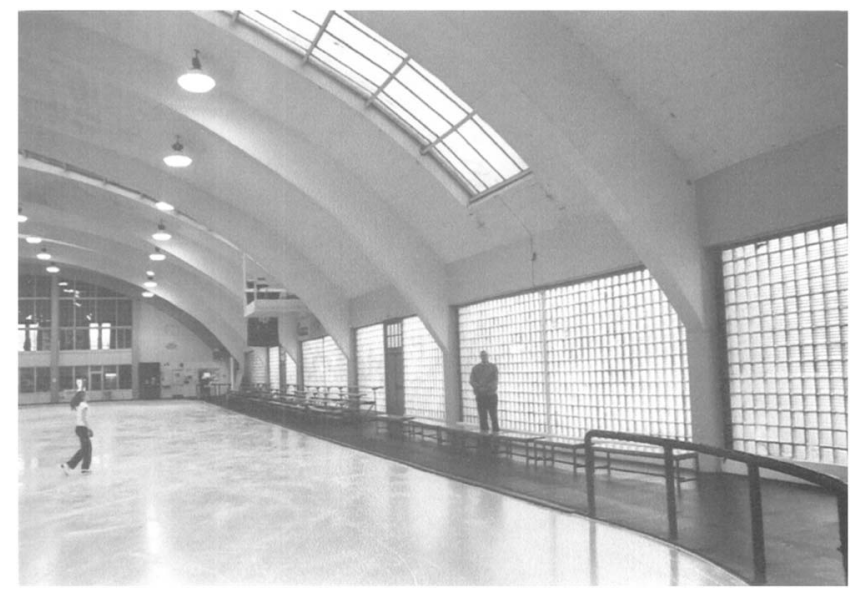

Fig. 1. Interior view of the Philadelphia Skating Club as it looks today (photo by David Billington) 


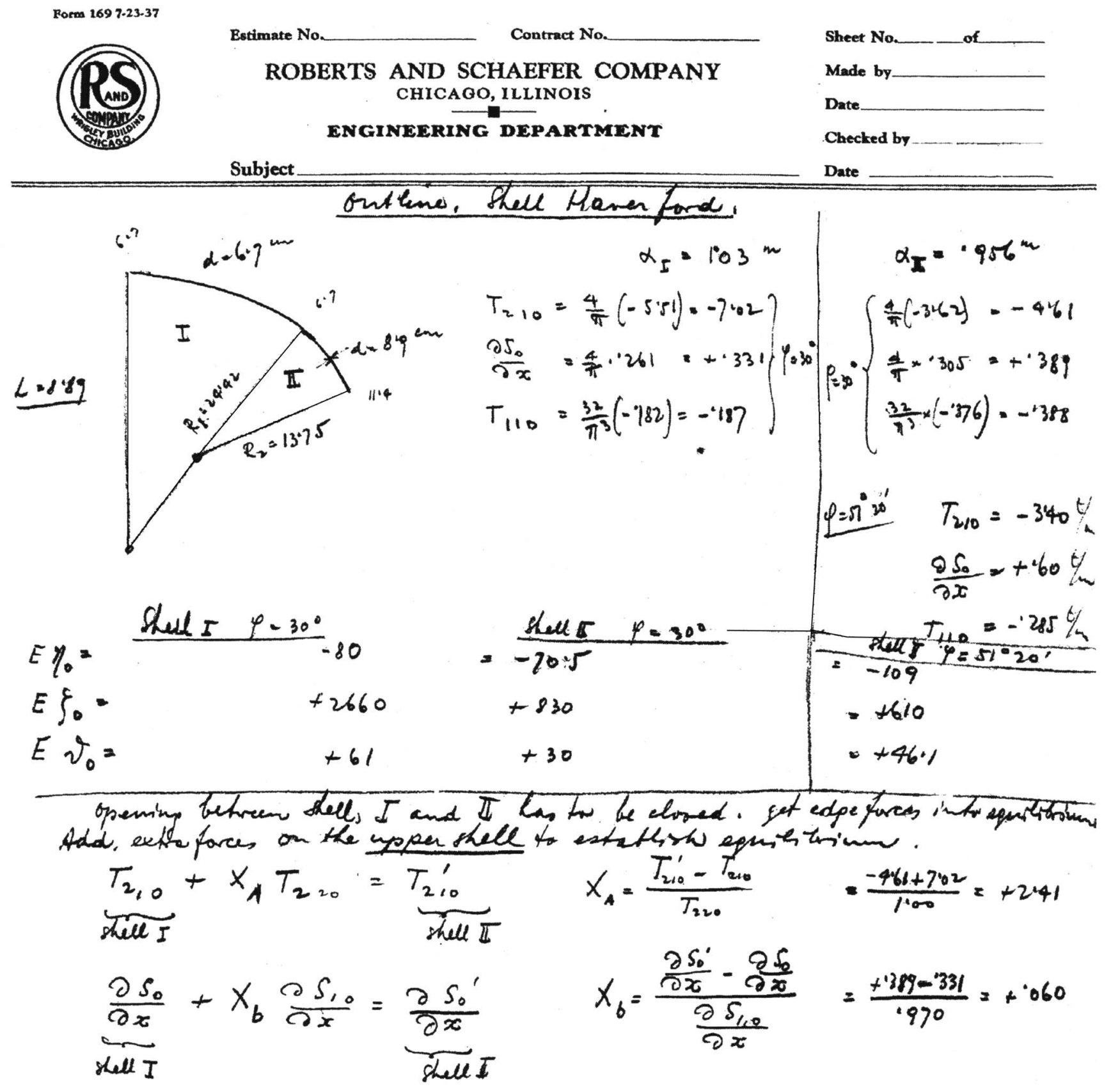

Fig. 2. Page from original design calculations (with permission of the Princeton Maillart Archive).

Structural engineering students must learn their tradition of landmark structures designed by engineers who concurrently sought both competitive cost and visually striking forms. They must also learn that the ability to create such works depends upon solid technical study as well as substantial field experience. Further, these works inevitably had initial conceptual designs that were based on elementary mathematics, coupled with a clear understanding of physical constraints.

To demonstrate that such designs are a part of our tradition, we explain some heretofore unpublished design calculations of Anton Tedekso. His design for the Philadelphia Skating Club in Haverford, Pa., is an exemplary structure that has proved to be durable and continues to be an inviting form nearly 70 years after its completion, as seen in Fig. 1. Because of their remarkable endurance, such concrete structures need to be studied, emulated, and preserved. Boothby and co-workers make a convincing case for the preservation of such historic thin-shell concrete structures (Boothby and Rosson 1998; Boothby et al. 2005).

The Philadelphia Skating Club was completed immediately after the Hershey Ice Arena. The form that Tedesko designed for the Philadelphia skating club clearly borrows from and improves upon that at Hershey, both structurally and aesthetically. Although it is true that Tedesko worked with architect E. Nelson Edwards at Philadelphia, the Skating Club's web page incorrectly attributes the roof design to Edwards, instead of to Tedesko. (Skating Club 2005). We support this claim with the calculations which were recently examined at the Princeton Maillart Archives (Tedesko 1937). These calculations show that the form of the roof and supporting arches arose from an engineering imagination that was technically rational and visually striking. Tedesko himself stated 


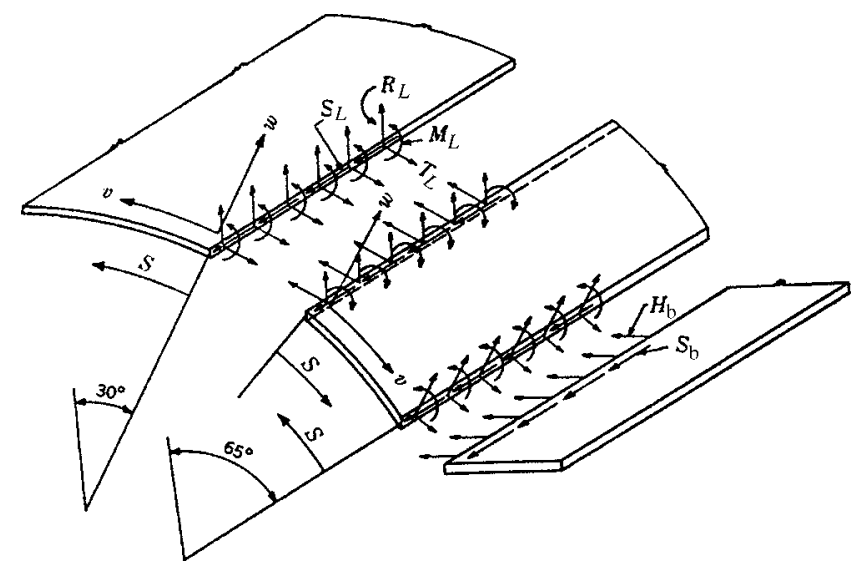

Fig. 3. Continuity of stress resultants

that the Philadelphia Skating Club "was the best-looking shell structure of the 1930's" (Tedesko 1978). It is instructive to explore the creative process that Tedesko used to design first the shape and thickness of the roof, and then the profile of the supporting arch ribs. Even more important is our intent to show the careful and conservative manner in which Tedesko dimensioned the arches and edge beams to ensure safety, durability, and reasonably clear form.

\section{Determining the Form of the Roof}

The top of Fig. 2 depicts the trace of the thin shell concrete roof that spans $35.45 \mathrm{~m}(116.3 \mathrm{ft})$. At the crown, the thin shell roof is $6.7 \mathrm{~cm}(25 / 8$ in.) thick and it thickens to $11.4 \mathrm{~cm}(41 / 2 \mathrm{in}$.) near the springing point. Tedesko chose to have the centerline of the shell follow two circular traces which are referred to as Shell I, the upper shell and Shell II, the lower shell in Fig. 2. The upper shell has a radius of $24.42 \mathrm{~m}$ (80 ft $1 \mathrm{in}$.) and extends $30^{\circ}$ from the crown. Along the horizontal axis, this juncture between the upper and the lower shells occurs $12.2 \mathrm{~m}$ (40 ft) horizontally from the crown (Tedesko 1939). At the start of the lower shell, the thickness is $8.9 \mathrm{~cm}(31 / 2 \mathrm{in}$.) and the radius is $13.75 \mathrm{~m}(45 \mathrm{ft}$ 1 in.). The lower shell continues for another $21^{\circ}$. Tedesko chose the radii of the upper and lower shells based on his experience with the newly built Hershey Ice Arena, where we assumed (Saliklis and Billington 2003) that the radius of curvature was dictated by stability concerns. Tedesko's goal here was to stiffen the shell as it approached its lower edge, yet to do so in a manner which still allowed for ease of construction. The increased curvature of the lower shell naturally stiffens the roof, yet it also introduces a stress concentration at the point of juncture between the upper and the lower shells. The bottom of Fig. 2 shows a small part of the complex analysis (developed in Germany) that Tedesko used to ensure that the discontinuity would not produce dangerous stresses at the point of juncture, shown at $30^{\circ}$ from the crown in Fig. 3. (Design 1952). The trace of the shell is seen at the top of Fig. 2 and is shown in Fig. 4. Fig. 4 is recreated from the original blueprints of the arena. The edge beam can be vertical as in the Philadelphia Skating Club, or horizontal as shown in Fig. 3.

\section{Determining the Form of the Ribs}

Having the shell profile, Tedesko could determine the shape of the supporting ribs which are shown in Fig. 1. As was done with the Hershey calculations (Saliklis 2003), Tedesko could then perform the statically indeterminate structural analyses on the arch ribs which lead to minimal bending. Stresses were of no great concern here. We recreated Tedesko's structural analyses with simple hand calculations as well as with modern computer modeling. In these hand calculation models, we assumed that the ribs carried the entire shell load and rib load. When comparing results from the arch rib alone to results from the final model which combines rib and shell, it is apparent that the actual rib experiences small bending moments (see Table 1). This is so because the shell carries a substantial portion of the load and the entire rib is greatly stiffened by the shell, which causes much less strain (and stress) compared to the simpler two or three hinged arch. Table 1 summarizes the bending moments in the ribs. We conclude that the ribs' primary purpose is to assure that the shell will not buckle. Our examination of the combined shell and rib performance leads us to conclude that Tedesko was blending his design experience and insight with careful state of the art analysis. He was demonstrating that the thin shell form is efficient, thus and makes the

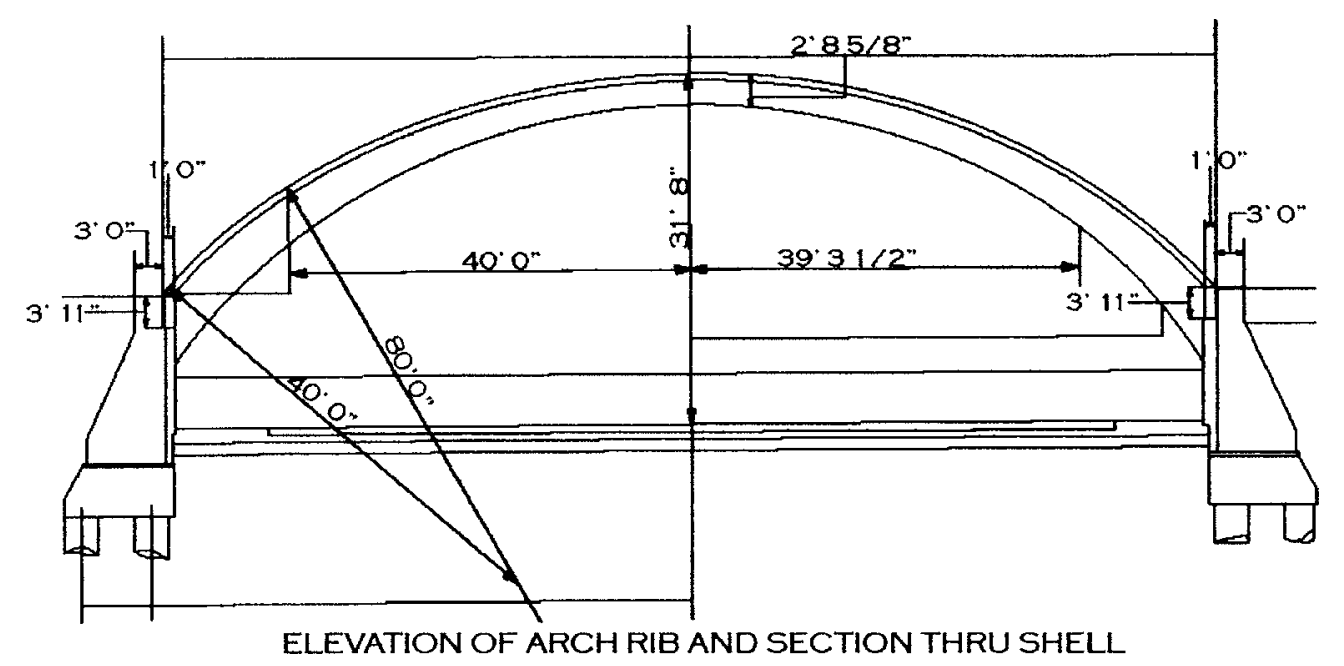

Fig. 4. Trace of centerline of thin shell roof (drawing by Andrij Kyfor based on original blueprints) 


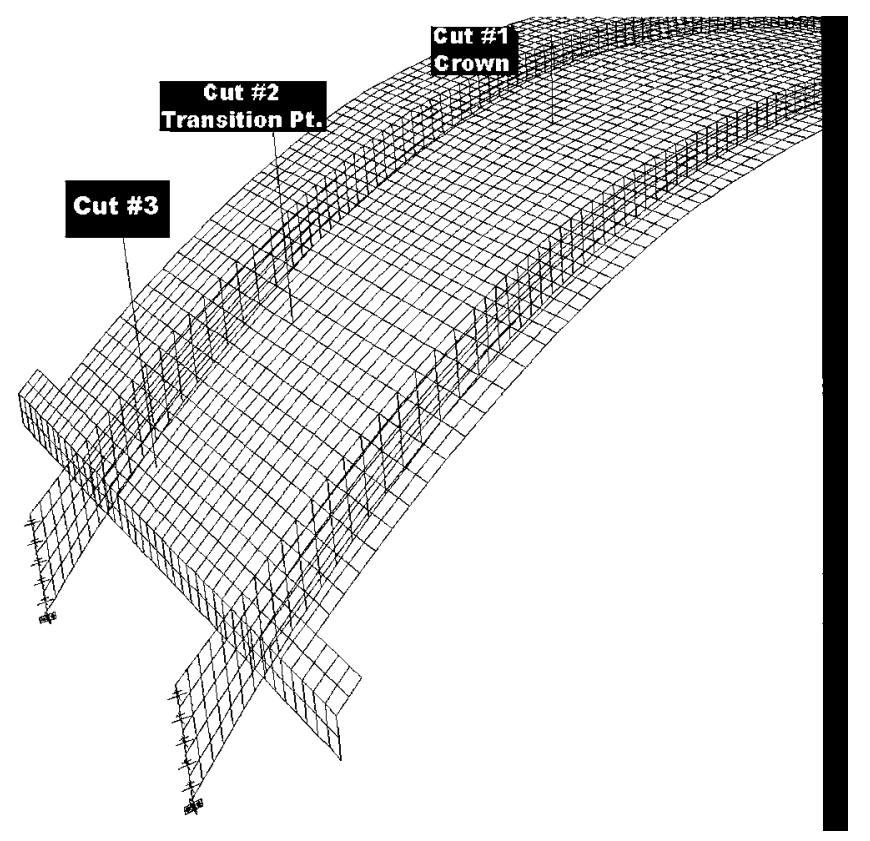

Fig. 5. Location of investigated cross sections in rib (drawing by Sigita Saliklis, based on computer model of shell)

Philadelphia Skating Club as simple as possible. His use of classical circular forms demonstrated that large roof spans can be covered with a very small amount of concrete, providing a permanent fire-proof durable structure.

\section{Analysis of the Edge Beam}

We provide an analysis of the edge beam to show the conservative nature of Tedesko's thinking in the case of a complex interaction of arch, shell and beam. He used a simplified and conservative method of obtaining the stress distribution along a cross section of edge beam, clearly seen above the block glass windows in Fig. 1. To demonstrate that his approach was indeed conservative, representative stress resultants obtained from the computer model are shown in Fig. 6 and summarized in Table 2. The values of axial force $(P)$ and bending moment $(M)$ in Table 2 were extracted from the finite-element results. Axial stress was recorded at different heights of the beam, from the top through the middle to the bottom of the beam, at Cuts 4, 5, and 6 shown in Fig. 6.

The 1937 calculations shown in Fig. 7 solve for the stresses in the edge beams by considering the vertical loads directly on the beams alone, plus the vertical and in plane shearing forces arising from the shell-beam system under shell loadings. The

Table 1. Bending Moments in Rib due to Dead Load

\begin{tabular}{lccc}
\hline $\begin{array}{l}\text { Distance } \\
\text { from crown }\end{array}$ & $\begin{array}{c}\text { Three-hinge } \\
\text { arch }\end{array}$ & $\begin{array}{c}\text { Two-hinge } \\
\text { arch }\end{array}$ & $\begin{array}{c}\text { Actual } \\
\text { arch }\end{array}$ \\
\hline Cut $10 \mathrm{~m}$ & & $-6.3 \mathrm{t} \mathrm{m}$ & $2.7 \mathrm{t} \mathrm{m}$ \\
$(0 \mathrm{ft})$ & 0 & $(-46 \mathrm{ft} \mathrm{kips})$ & $(20 \mathrm{ft} \mathrm{kips})$ \\
Cut $212.2 \mathrm{~m}$ & $24.3 \mathrm{t} \mathrm{m}$ & $20.6 \mathrm{t} \mathrm{m}$ & $-1.4 \mathrm{t} \mathrm{m}$ \\
$(40 \mathrm{ft})$ & $(178 \mathrm{ft} \mathrm{kips})$ & $(151 \mathrm{ft} \mathrm{kips})$ & $(-10 \mathrm{ft} \mathrm{kips})$ \\
Cut $315.9 \mathrm{~m}$ & $21.7 \mathrm{t} \mathrm{m}$ & $20.6 \mathrm{t} \mathrm{m}$ & $-4.5 \mathrm{t} \mathrm{m}$ \\
$(52.36 \mathrm{ft})$ & $(159 \mathrm{ft} \mathrm{kips})$ & $(151 \mathrm{ft} \mathrm{kips})$ & $(-33 \mathrm{ft} \mathrm{kips})$ \\
\hline
\end{tabular}

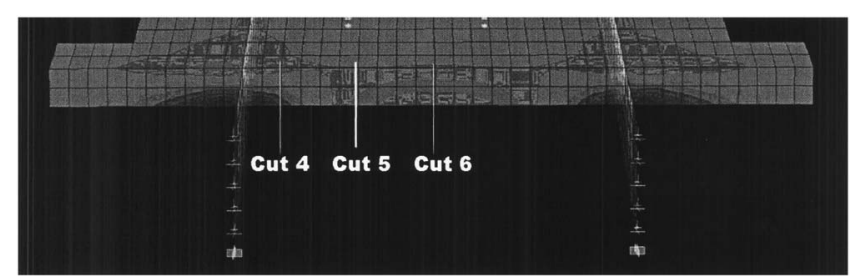

Fig. 6. Axial stress resultants in edge beam

total vertical loads taken were $1.25 \mathrm{t} / \mathrm{m}$, assumed to be uniformly distributed along the length of $8.89 \mathrm{~m}(29.2 \mathrm{ft})$ of a simplesupported beam, resulting in a midspan bending moment of $w \times L^{2} / 8=1.25 \times 8.89^{2} / 8=12.3 \mathrm{t} m$. This simply supported moment $w L^{2} / 8$ is reduced by the shear flow stress resultant $S_{b}$ shown in Fig. 3. The net axial force of this $S_{b}$ flow is labeled as $Z$ in Fig. 7. The change in the shell edge shear forces $\partial S / \partial x$ $=1.54 \mathrm{t} / \mathrm{m}^{2}$ directed toward each beam support from midspan. Integrating this stress twice over one half of the edge beam span gives the total tensile force $Z$ acting at the beam top

$$
Z=\partial S / \partial x \int_{0}^{L / 2} x d x=1.54 \frac{L^{2}}{8}=(1.54) \frac{8.89^{2}}{8}=15.2 \mathrm{t}
$$

The axial force $Z$ acts at a distance $e$ of $0.42 \mathrm{~m}(1.38 \mathrm{ft})$. This eccentricity $e=$ distance from where the roof shell contacts the edge beam, to the edge beam's centroidal axis (as shown in Fig. 9). This combined loading creates the final maximum edge beam bending moment

$$
M=\frac{w L^{2}}{8}-Z e=12.5 \mathrm{tm}-15.4 \mathrm{t} \times 0.42 \mathrm{~m}=6.05 \mathrm{tm}
$$

The area of the edge beam is $0.304 \mathrm{~m}$ (12 in.) $\times 1.194 \mathrm{~m}$ ( $3 \mathrm{ft} 11$ in. $)=0.363 \mathrm{~m}^{2}$. The section modulus is $0.304 \times 1.194^{2} / 6$ $=0.0722 \mathrm{~m}^{3}$ from which the top and bottom edge beam stresses are $15.4 / 0.363 \mp 6.05 / 0.0722=(42.4 \mp 83.8) \mathrm{t} / \mathrm{m}^{2}$, respectively, $-41.4 \mathrm{t} / \mathrm{m}^{2}$ (compression) and $126.2 \mathrm{t} / \mathrm{m}^{2}$ (tension). These are highly conservative values for two reasons. First, the edge beam is continuous over the supports and hence the midspan moments will be nearer $w L^{2} / 24$ than $w L^{2} / 8$ and second, some of the vertical loads will be transferred to the arches before they reach the edge beam. The result of our finite-element analysis indicates the influence of these significant differences. Table 2 summarizes our results and posts Tedesko's conservative numbers as well. To see another view of this edge beam, refer to Fig. 8.

Finally, in Fig. 9 we recreate the bending stress distribution at the center span of the edge beam. This bending stress diagram

\begin{tabular}{|c|c|c|c|c|}
\hline $\begin{array}{l}\text { Distance } \\
\text { from } \\
\text { edge }\end{array}$ & $\begin{array}{c}\text { Axial force } \\
\text { SAP }\end{array}$ & $\begin{array}{c}\text { Bending } \\
\text { moment SAP }\end{array}$ & $\begin{array}{l}\text { Axial force } \\
\text { Tedesko }\end{array}$ & $\begin{array}{l}\text { Bending } \\
\text { moment } \\
\text { Tedesko }\end{array}$ \\
\hline $\begin{array}{l}\text { Cut } 40.88 \mathrm{~m} \\
(2.9 \mathrm{ft})\end{array}$ & $\begin{array}{c}-6.4 \mathrm{t} \\
(-14.4 \mathrm{kip})\end{array}$ & $\begin{array}{c}-2.4 \mathrm{t} \mathrm{m} \\
(-17.5 \mathrm{ft} \text { kip })\end{array}$ & $\begin{array}{c}\text { Not } \\
\text { calculated }\end{array}$ & $\begin{array}{c}\text { Not } \\
\text { calculated }\end{array}$ \\
\hline $\begin{array}{l}\text { Cut } 52.65 \mathrm{~m} \\
(8.7 \mathrm{ft})\end{array}$ & $\begin{array}{c}6.5 \mathrm{t} \\
\text { (14.7 kip) }\end{array}$ & $\begin{array}{c}0.7 \text { t m } \\
(5.4 \text { ft kip) }\end{array}$ & $\begin{array}{c}\text { Not } \\
\text { calculated }\end{array}$ & $\begin{array}{c}\text { Not } \\
\text { calculated }\end{array}$ \\
\hline $\begin{array}{l}\text { Cut } 64.42 \mathrm{~m} \\
(14.5 \mathrm{ft})\end{array}$ & $\begin{array}{c}11.1 \mathrm{t} \\
(24.9 \mathrm{kip})\end{array}$ & $\begin{array}{c}1.5 \text { t m } \\
\text { (10.8ft kip) }\end{array}$ & $\begin{array}{c}15.4 \text { t } \\
(34.6 \mathrm{kip})\end{array}$ & $\begin{array}{c}6.05 \mathrm{t} \mathrm{m} \\
(44.6 \mathrm{ft} \mathrm{kip})\end{array}$ \\
\hline
\end{tabular}

Table 2. Summary of Edge Beam Analysis 


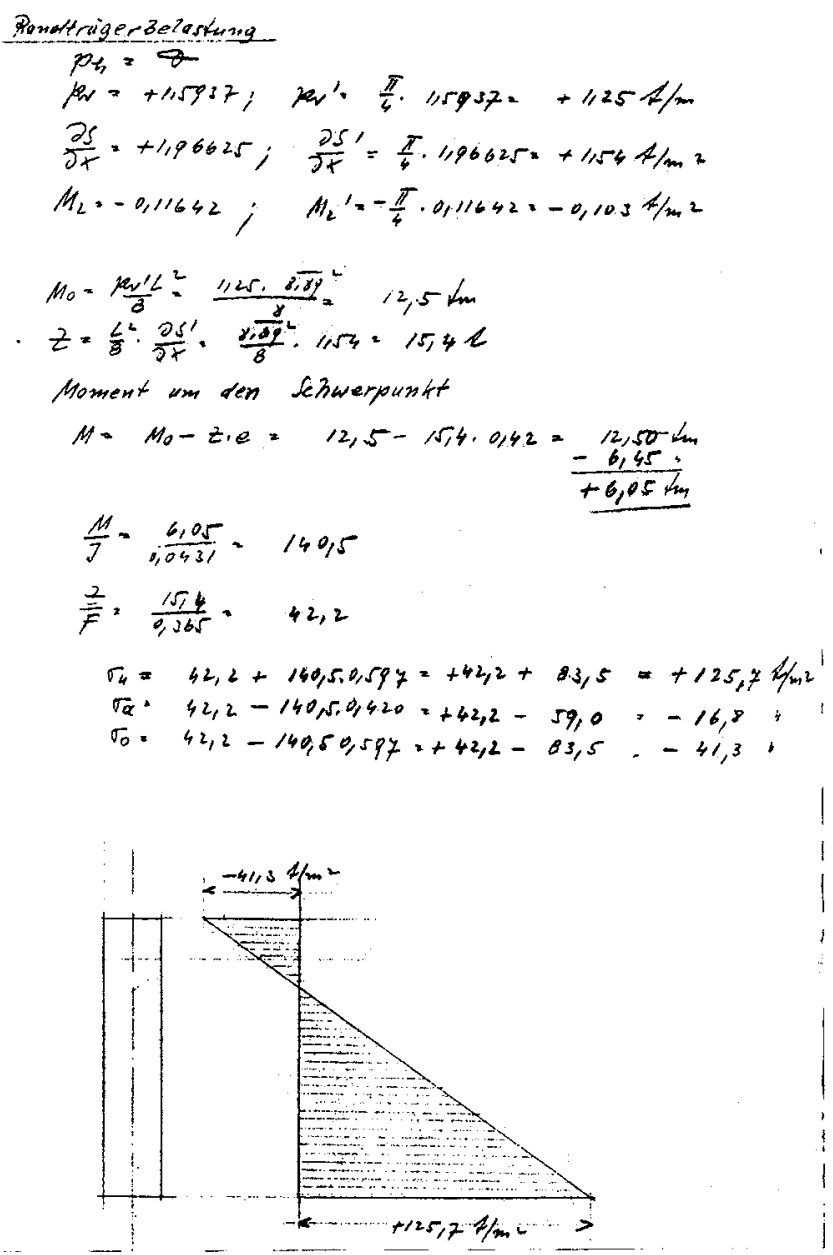

Fig. 7. Original design sheet analyzing $1 \mathrm{ft} \times 3.9 \mathrm{ft}$ edge beam

also appears in the 1937 calculations shown in Fig. 7. Superimposed on this diagram is the diagram generated from the computer model.

There is concern today that concrete structures like those of Tedesko cannot be built because of their high cost of construction (Meyer 2005). This argument is partly true but only because it omits two factors. One is the passion that people like Tedesko brought to his new ideas which enabled him to convince de-

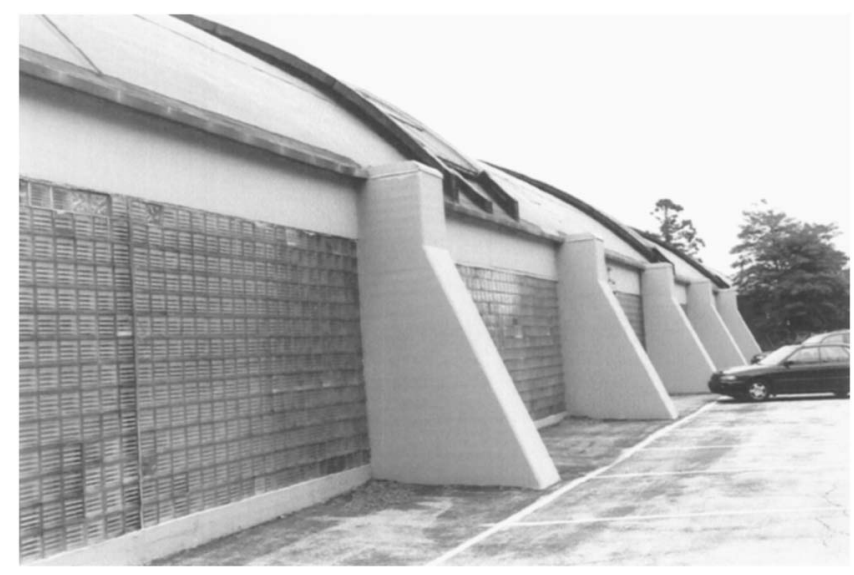

Fig. 8. Exterior view showing edge beam (photo by David Billington)

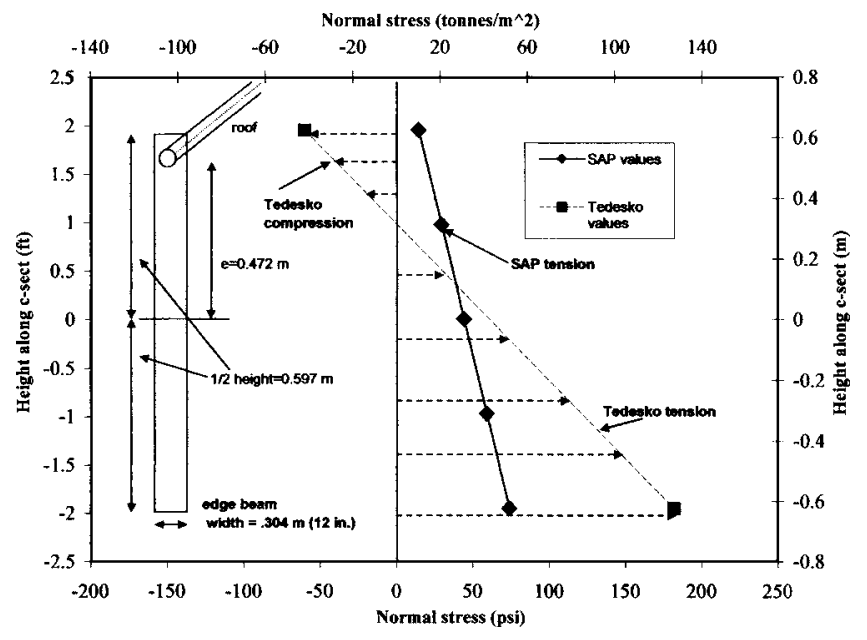

Fig. 9. Stress profile of edge beam at centerline (Cut 6) of edge beam

signers and builders of the reasonable economy that was possible. The other factor is the growing trend of design-build which can bring back the building of sustainable forms in concrete that are designed with constructability always at the forefront of the engineer's mind. This is what made Tedesko a master builder in the 1930s, carrying on from his German mentor Ulhrich Finsterwalder, and what accounts also for the remarkable and competitive thin shell concrete structures of Heinz Isler, Felix Candela, and Pier Luigi Nervi (Tedesko 1972).

\section{Conclusion}

This paper documents an important structure in the career of a major engineer in the grand tradition of structural engineering. Original archival works are presented here and explained for the engineering community, both students and professionals, so that the structural engineering profession can take note of the major landmarks in our tradition. Understanding and valuing such landmarks will aid in their preservation and most importantly will serve to guide designers in the new century in their search for structural forms and details that will be exemplary in the same way as the shells associated with Anton Tedesko.

\section{Acknowledgments}

The writers gratefully acknowledge that partial support for this work was provided by the National Science Foundation, Award No. 0095010 to Princeton University. They are also grateful to the late Anton Tedesko who gave his professional papers to the Princeton Maillart Archives and to his widow Sally Tedesko for her subsequent gifts of additional papers.

\section{References}

Boothby, T., Parfitt, M., and Roise, C. (2005). "Case studies in diagnosis and repair of historic thin-shell concrete structures." APT Bull., 36, 3-11.

Boothby, T., and Rosson, B. (1998). "Preservation of historic thin-shell concrete structures." J. Archit. Eng., 4(1), 4-11. 
Design of Cylindrical Concrete Shell Roofs. (1952). ASCE manuals of engineering practice, No. 31, ASCE, Reston, Va., 82.

Meyer, C. (2005). "Do concrete shells deserve another look?" Concr. Int., $27(10), 43-50$.

Saliklis, E., and Billington, D. (2003). "The Hershey Arena: Anton Tedesko's pioneering form." J. Struct. Eng., 129(3), 278-285.

Skating Club. (2001). "History." 〈http://www.pschs.org/Set_About_ main_history.htm $\rangle$ (Feb. 28, 2005).
Tedesko, A. (1937). "Haverford-Penn Skating Hall." Maillart archives, Princeton Univ., Princeton, N.J.

Tedesko, A. (1939). "Thin concrete shell roof for ice skating arena." Engineering News Record, Feb. 16.

Tedesko, A. (1972). "How have concrete shell structures performed?" IASS bulletin, no. 73, 3-13.

Tedesko, A. (1978). “Autobiography." Maillart archives, Princeton Univ., Princeton, N.J. 